\title{
Excentrochloris fraunhoferiana sp. nov. (Botrydiopsidaceae, Xanthophyce- ae), a new aerophytic species from the surfaces of modern buildings
}

\author{
Wolfgang HofBAuer ${ }^{1 *}$, Georg GÄRTNER ${ }^{2}$, Thorsten RenNEBARTH ${ }^{1}$, \\ Klaus SEDLBAUER ${ }^{1}$, Florian MAYER ${ }^{1} \&$ Klaus BReUER $^{1}$
}

${ }^{1}$ Fraunhofer-Institute for Building Physics Holzkirchen, Fraunhoferstraße 10, D-83626 Valley, Germany; * corresponding authore-mail: wolfgang.hofbauer@ibp.fraunhofer.de

${ }^{2}$ Innsbruck University, Institute of Botany, Sternwartestraße 15, A-6020 Innsbruck, Austria; Georg.Gaertner@ uibk.ac.at

\begin{abstract}
A new aerophytic species of the xanthophycean genus Excentrochloris - Excentrochloris fraunhoferiana Hofbauer, Gärtner, Rennebarth, Sedlbauer, Mayer et Breuer from a building surface is described. Light microscopically investigation and sequence analyses showed a clear relationship of the new alga to Botrydiopsis constricta BROADY. Cytomorphology and reproduction of the new species was investigated on cultures. E. fraunhoferiana differs from the type species $E$. gigas by bigger size of adult vegetative cells with obligate thickening of wall, and none amoeboid zoospores with one chloroplast. Adult zoospores are peripherically arranged in the sporangia. The relation to Botrydiopsis constricta is discussed in comparison with characters of E. fraunhoferiana.
\end{abstract}

Key words: Biodiversity, Biogenic crusts, Building relevant microorganisms, Excentrochloris, Taxonomy, Xanthophyceae

\section{Introduction}

The biodiversity of algae appearing on buildings is composed of special adapted forms. Taxonomic investigations of the primary biological succession on the outer surface of buildings within the scope of a doctoral thesis documented an unexpected rich biodiversity (HofBAUER 2007). Many taxa could be assigned even to species level, some would need further investigation and some were found to be new species which have not been described yet. These investigations listed in total more than 75 different species of algae (cyanoprokaryota and eukaryotic algae), apart from fungi, bacteria, lichens and animal organisms (in total more than 180 species), which are represented mainly as cultures. More than 20 species of algae have been identified for the first time as components of the primary biological succession of biological crusts on buildings. Among them a very peculiar species of Xanthophyceae has been isolated which appeared as an unknown species of the genus Excentrochloris (HOFBAUER 2007).

Within the last few years some new genera and species of the Xanthophyceae have been de- scribed from various habitats. However it is quite a surprise that on an only a few years old surface of a modern building coating a hitherto unknown species of the yellow-green algae (Xanthophyceae) was found. In the following the new species Excentrochloris fraunhoferiana is described and depicted.

\section{Materials and Methods}

For the investigations, already established cultures were used which are maintained in the culture collection of building relevant microorganisms at the Fraunhofer-Institute for Building Physics. Additional pure cultures of the new species were set up, outgoing from still existing enrichment and interim cultures of the original analysis.

The strains originate from the surface of one specimen representing a coating of a so called mineral coating (lime or cement bound) without overlying paint. The specimen has been exposed to the local climate for three years at the Fraunhofer-Institute for Building Physics, Holzkirchen. Samples of the coating were taken and treated aseptically according to the procedure described in HOFBAUER (2007). In spite of isolation into unialgal cultures, some strains still are 
Table 1. Used Primers for SSU, according to F. RIMET (personal communication).

\begin{tabular}{ll}
\hline $\begin{array}{l}\text { Designati- } \\
\text { on of DNA } \\
\text { Segment }\end{array}$ & Sequence \\
\hline $1 \mathrm{~F}$ & AAC CTG GTT GAT CCT GCC AGT A \\
$528 \mathrm{~F}$ & GCG GTA ATT CAA GCT CCA A \\
$1055 \mathrm{~F}$ & GGT GGT GCA TGG CCG TTC TT \\
$1528 \mathrm{R}$ & CTT CTG CAG GTT CAC CTA C \\
$536 \mathrm{R}$ & AAT TAC CGC CGC KGC TGG CA \\
1050R & ACG GCC ATG CAC CAC CAC CCA T \\
\hline
\end{tabular}

contaminated with bacteria. Only axenic algal strains or strains free from fungal contaminations were used. Strains are deposited in the culture collection of building relevant microorganisms established at the Fraunhofer-Institute for Building Physics, Holzkirchen) and labelled as: HOKI A 13 - A 20 and HOKI A 318 - A 321. Additionally, subcultures of the investigated strains were transferred to the algal culture collection at the botanical institute of the Innsbruck University (ASIB, GÄRTNER 2004).

The different strains were cultivated on solidified Bold's Basal Medium (BBM), modified according to Bischoff \& Bold (1963), and also described in EtTL \& GÄRTNER (1995). Cultures were maintained in a 12 to $12 \mathrm{~h}$ cycle (light $-25^{\circ} \mathrm{C}$; dark, $16^{\circ} \mathrm{C}$ ) or according to long day conditions $\left(16 \mathrm{~h}\right.$ daylight, $25^{\circ} \mathrm{C}, 8 \mathrm{~h}$ darkness, $16^{\circ} \mathrm{C}$ ) on culture slants or on agar plates in Petri-dishes sealed with Parafilm within culture-cabinets (Binder company) equipped with special culture fluorescent tubes (Osram company). Unialgal cultures were propagated by periodically inoculation onto new culture medium. For investigation of zoospore development additional clones were grown in liquid cultures, with BBM.

To prove the position of the new alga within Xanthophyceae also chloroplast pigment extracts were produced by use of acetone, according to DALES (1960). Absorption spectra of the acetone-extracts were taken by use of a standard photometer (Perkin-Elmer, Lambda 2 UV/VIS spectrophotometer).

Microscopic examination was done by light microscope (Axioscop 40, Zeiss Company) using magnifications up to $x 1000$. Photographic documentation was performed with a Sony digital camera (MPEGMOVIEEX). Size measurements on living cells were made from young clones in the exponential phase, in the phase of zoospore development, and from older cultures in the stationary phase. Lugol's iodine was used for contrasting the cell contents and for checking the presence or absence of starch. With use of Indian ink and methylene blue the presence of mucilage was tested. Sudan 4 was used to stain for oil. Drawings of the new species were done with Indian ink with the use of a Camera Lucida.

For a first information on the phylogenetic position of the new alga and to check consistency with morphologic data overview genetic analyses were performed. Deoxyribonucleic acid (DNA) was extracted by use of the QIAamp ${ }^{\circledR}$ DNA Mini Kit (QIAGEN). The small subunit of the ribosomal DNA (18S rDNA; SSU) genes and of the large subunit of the ribulose-1,5-bisphosphate carboxylase/oxygenase $(r b c \mathrm{~L})$ genes were amplified from DNA-extracts via the polymerasechain-reaction (PCR) using the Silver Star Polymerase (Eurogentec) with the provided buffer and 2mM Magnesium Chloride $\left(\mathrm{MgCl}_{2}\right)$ For SSU primers according to F. RIMET (personal communication) were used (table 1) whereas for $r b c L$ primers according to DAUGBERG \& ANDERSEN (1997) were taken. PCR products were cleaned by using the QIAquick ${ }^{\circledR}$ PCR Purifikation Kit (QIAGEN). Sequencing of PCR products was done by an external contract partner. The sequences were compared with those of other heterokont algae obtained from GeneBank; table 2 shows which were used for $r b c \mathrm{~L}-$ sequence phylogenetics. Sequences were aligned using Geneious (Biomatters). The complete alignments are available from the corresponding author on request. Parsimony analysis was conducted using PAUP (Sinauer Associates; Swofford 2003). Phylogenetic bootstrapping was implemented in PAUP to assess relative support for branches in the most parsimonious trees (100x replicates for a first overview for each data set; Swofford 2003; Sundberg et al. 2008). Bayesian Analysis was conducted using the Mr Bayes-Plugin of Geneious. The applied Hasegawa-Kishono-Yano model (HKY85) nucleotide substitution model is provided by Mr Bayes (HuElsEnBECK \& RonQuist, 2001). Maximum likelihood analysis was not performed because this method does not have an evolutionary background.

\section{Results}

The modern approach in algal classification is to use the so called ,polyphasic approach" (Aslam et al. 2007; Pröschold \& Leliaert 2007; Neustupa et al. 2009). This usually means the establishment of simultaneous and complementary consideration of morphological, biochemical and genetic characters.

First step to elucidate the position of the investigated alga within the class Xanthophyceae was investigation with light microscope and pigment analysis. 
Table 2. Accession numbers of the $r b c \mathrm{~L}$ sequences.

\begin{tabular}{|c|c|c|}
\hline Accession No. & Organism & Strain-No. \\
\hline AF476927 & Asterosiphon dichotomus & not specified \\
\hline AB280609 & Botrydiopsis alpina & not specified \\
\hline AJ579569 & Botrydiopsis callosa & not specified \\
\hline AJ579566 & Botrydiopsis constricta & not specified \\
\hline EF589158 & Botrydiopsis constricta & $\mathrm{LCR}-\mathrm{C}$ \\
\hline EF589159 & Botrydiopsis constricta & LCR-P \\
\hline AF015587 & Botrydiopsis intercedens & not specified \\
\hline AJ579570 & Botrydiopsis intercedens & not specified \\
\hline AJ579568 & Botrydiopsis pyrenoidosa & not specified \\
\hline AF465706 & Botrydium becharianum & not specified \\
\hline AF465708 & Botrydium cystosum & not specified \\
\hline AF064743 & Botrydium stoloniferum & not specified \\
\hline AJ579564 & Botryochloris sp. ,Southern Victoria Land“ & not specified \\
\hline AJ874707 & Bumilleria sicula & not specified \\
\hline AJ874703 & Bumilleriopsis filiformis & not specified \\
\hline AJ579572 & Bumilleriopsis petersenia & not specified \\
\hline AJ874706 & Bumilleriopsis sp. & SAG 22.93 \\
\hline AB280604 & Chattonella antiqua & not specified \\
\hline DQ273989 & Chattonella ovata & not specified \\
\hline DQ273994 & Chattonella ovata & not specified \\
\hline AJ579565 & Chlorellidium pyrenoidosum & not specified \\
\hline AJ580948 & Chlorellidium $\mathrm{sp.}$ & SAG $811-1$ \\
\hline AJ580947 & Chlorellidium tetrabotrys & SAG 5.90 \\
\hline AJ580947 & Chlorellidium tetrabotrys & SAG 5.90 \\
\hline AJ287862 & Choristocarpus tenellus & SGAD-103 \\
\hline DQ273999 & Haramonas dimorpha & not specified \\
\hline AB280608 & Haramonas dimorpha & not specified \\
\hline AF084610 & Heterococcus caespitosus & not specified \\
\hline AM421003 & Heterococcus chodatii & SAG 835-3 \\
\hline AJ580926 & Heterococcus pleurococcoides & not specified \\
\hline AJ579575 & Heterococcus protonematoides & not specified \\
\hline AJ580925 & Heterococcus sp. ANT & not specified \\
\hline AF064744 & Mischococcus sphaerocephalus & not specified \\
\hline AJ874700 & Ophiocytium capitatum & not specified \\
\hline AJ874699 & Ophiocytium majus & not specified \\
\hline AJ874701 & Ophiocytium parvulum & not specified \\
\hline AM421005 & Phaeobotrys solitaria & SAG 15.95 \\
\hline AF064746 & Phaeothamnion confervicola & not specified \\
\hline
\end{tabular}


Table 2 Cont.

\begin{tabular}{lll}
\hline AF069499 & Pleurochloridella botrydiopsis & not specified \\
AJ579567 & Pleurochloris meiringensis & not specified \\
AJ579573 & Bumilleriopsis pyrenoidosa & not specified \\
AJ580924 & Pseudopleurochloris antarctica & not specified \\
AJ579574 & Sphaerosorus composita & not specified \\
AF155585 & Tetrasporopsis fuscescens & not specified \\
AF084611 & Tribonema aequale & not specified \\
AY682399 & Tribonema elegens & not specified \\
AF465709 & Tribonema intermixtum & not specified \\
AJ874340 & Tribonema minux & not specified \\
AJ874338 & Tribonema ulotrichoides & not specified \\
AY682445 & Tribonema viride & not specified \\
AJ874336 & Tribonema vulgare & not specified \\
AJ874331 & Xanthonema bristolianum & not specified \\
AY682454 & Xanthonema debile & not specified \\
AY682398 & Xanthonema hormidioides & not specified \\
AY682455 & Xanthonema solidum & not specified \\
AJ874334 & Xanthonema tribonematoides & not specified \\
\hline
\end{tabular}

According to current knowledge the pigment profile in our investigation was typical for heterokont algae (WILHeLm et al. 1987).

The new form has solitary living cells combined with a considerable growth in size connected with multiple nuclei in vegetative cells. Firstly addressed as a new species within the genus Botrydiopsis Borzi (HoFBAUER 2007) it became clear after detailed investigation of cultures with light microscope that it is an unknown species of the genus Excentrochloris PASCHER.

\section{Excentrochloris fraunhoferiana HOFBAUER, Gärtner, Rennebarth, Sedlbauer, Mayer et Breuer Sp. nov.}

Diagnosis: Cellulae vegetativae singulae et multinucleatae. Cellulae maturae plerumque pyriformae, ellipsoideae, lagenariae vel fusiformae, rarae sphericae.

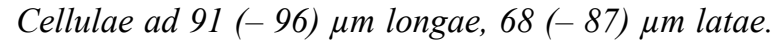
Membrana cellulae laevis firma, frequentis incrassatis inaequalis. Cellulae chloroplastibus numerosis, lentiformis, sine pyrenoide. Propagatio autosporis vel zoosporis multis (4.4- $6 \mu \mathrm{m}$ longae, 2.3 - $3.8 \mu \mathrm{m}$ latae), flagellis binis inaequalis, cum stigmate, in sporangis parietalis aggregatis.

Habitatio: Species aerophytica de superficie politionis apud institutionem fraunhoferianum ad viciniam Hol- zkirchen, Germania.

Iconotypus: figura nostra 1, ex culturam Hoki A 14. Cultura in collectione Algarum Universitatis Oenipontis (ASIB, Austria) deposita.

Vegetative cells are usually single, multinucleate, pyriform, ellipsoidal, lageniform or fusiform, rarely spherical, with size up to $91(-96) \mu \mathrm{m}$ in length and $68(-87) \mu \mathrm{m}$ in width. Chloroplasts are numerous and elongated-flattened, lens-shaped without pyrenoids. The cell wall is smooth (light microscope), always firm and often with unequal thickenings which become stratified in adult cells. Propagation is by zoospores and autospores. Zoospores are $4.4-6 \mu \mathrm{m}$ in length and $2.3-3.8 \mu \mathrm{m}$ in width. They are metabolic and possess two flagella of different length which are inserted slightly lateral from the cell pole. They always contain only one chloroplast and a red stigma.The are arranged peripherically within the sporangia.

Habitat: Aerophytic species collected from the surface of plaster at the Fraunhofer-Institute near Holzkirchen, Germany.

Holotypus: fixated (preserved) material from culture Hoki A 14 is deposited at the herbarium of the University at Innsbruck under designation (hic designatus) Fix-Hoki A 14. 
Iconotypus: our figure 1, from culture Hoki A 14. Cultures (ex-holotypes) deposited in the algal collection of the University at Innsbruck (ASIB, Austria) designated as Hoki A 14.

Species epithet ,fraunhoferiana": The name ,fraunhoferiana" of the new species is derived from the Fraunhofer society (named after Josef Ritter von Fraunhofer) and the "Fraunhofer-Institute for Building Physics", in Holzkirchen, Germany.

For Excentrochloris the pear-shaped, irregular elongated, even fusiform or lemon shaped adult cells are very characteristic (Fig. 1). Whereas young cells possess one or few disc shaped chloroplasts, adult ones have numerous elongated and flattened lens shaped chloroplasts, never spindle shaped. There are no pyrenoids visible (light microscopic investigation). In vegetative cells usually some of the chloroplasts are in parietal position but also many are scattered within the cell lumen (Fig. 2). As described by TsCHERMAKWOESS (1979) for Botrydiopsis alpina VISCHER also Excentrochloris fraunhoferiana shows often stacks of chloroplasts in vegetative cells. Up to now this arrangement of plastids is unique within xanthophyceae. Oil droplets within the cell plasma were identified using Sudan 4 . Whereas young cells often contain several colourless oil droplets, old cells may contain a considerable large yellow or orange oil-vacuole.

Soon after beginning of cell growth the cell wall develops local thickenings; only few cells remain with a regular firm membrane. This can be shown in a typical form at the frequent pyriform cells, in which the stalk like part shows a more or less thickened cell wall with a distinct stratification. In other cells the thickenings appear at both cell poles (Fig. 1).

Older adult cells with particular growth in size regularly show a partial casting of the membrane (Fig. 3). This is very unique. Often there remains a cap like part of the burst cell wall attached to the cell which allows estimation of the original size and form of the cell.

A further important diagnostic character is a special kind of protoplast fragmentation which is connected to the development of the cell wall. By means of aperture like increase of local cell wall thickenings at the „stem base“ or at a section of an ellipsoidal or fusiform cell a part of the protoplast may be segregated (Fig. 4). Even three portions can be formed. The parts of the proto-

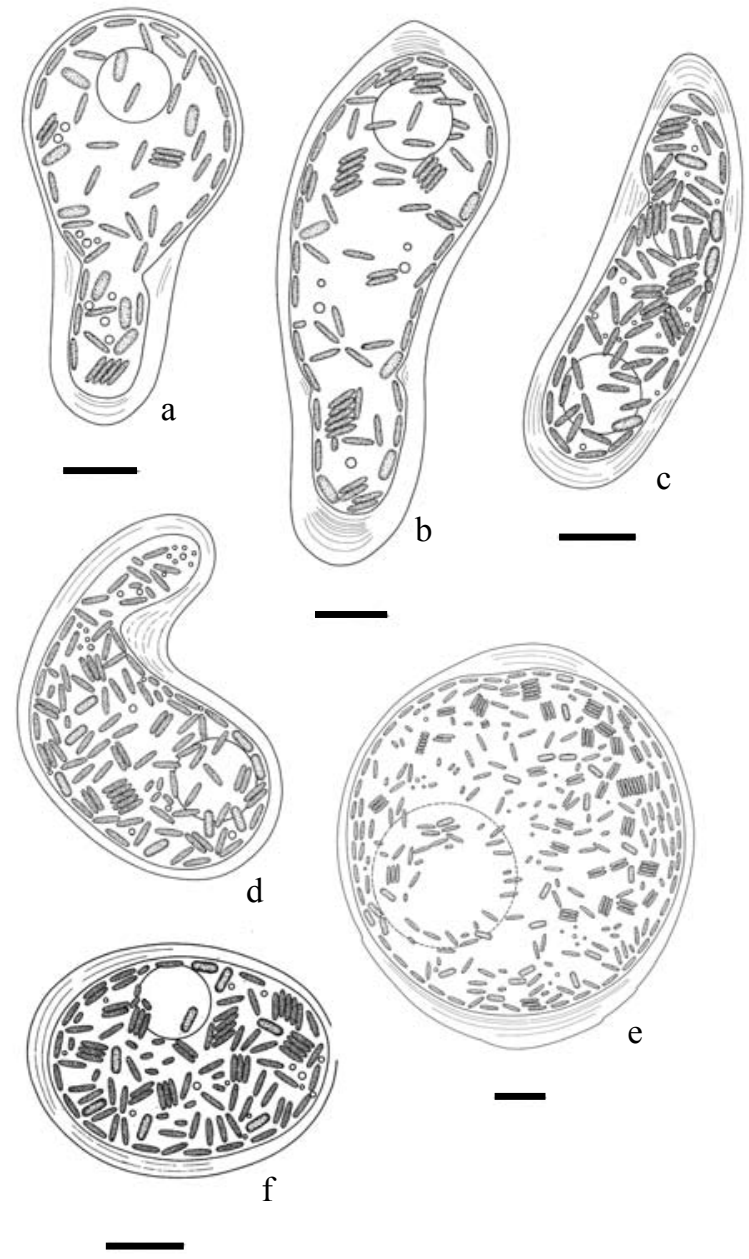

Fig. 1. Different typical forms of solitary adult cells. One or two small vacuoles within the cells are visible. Often stacks of chloroplasts can be recognized. The chloroplasts are shown in front view, side view and from above. Additionally small oil droplets are visible in vegetative cells. The largest cell (f) shows signs of a former partial casting of the membrane. Scale bar $10 \mu \mathrm{m}$.

plast are of undefined proportions, but mostly of distinctly different size. In contrast with BROADY (1976) a complete division of the cells never happens; the daughter protoplasts always remain enclosed in the mother cell wall. The further development of the daughter protoplasts often differs. Whereas the bigger portion soon may evolve into a zoo- or autosporangium the smaller remains in the vegetative phase, in which it usually gains further size. However sometimes the smaller protoplast degenerates and dies.

The normal propagation runs by zoospores and autospores. Zoospores are formed when mature sporangia from agar cultures are inoculated in fresh solidified or liquid medium. Even if adult sporangia are suspended in tap water zoospores may hatch. During different stages of the devel- 
opment of the coenoblasts they may convert to a zoosporangium, so not only fully sized cells but also rather small cells may release spores. In the first stage of zoospore formation the chloroplasts become transversally orientated in the periphery of the cell and a red stigma appears in each chloroplast (Fig. 5).

After the liberation of the zoospores there always remains a reticular residue of sterile plasma in the sporangia (Fig. 6). The zoospores which are produced in different numbers, according to the size of the zoosporangium are metabolic but do not form pseudopodia (Fig. 7a). They always contain only one chloroplast with a red stigma. The two flagella of the metabolic zoospores are inserted slightly laterally and at the apex of the cell are two hardly visible contractile vacuoles. After a short time as swarmers (often just a few minutes) the zoospores loose their flagella and develop into globular or ellipsoidal form and start to grow. The stigma is withdrawn soon and the chloroplasts become multiplied. Autospores are also supplied with a stigma in the beginning (Fig. 7b). Apart from small autospores which resemble rounded zoospores and possess only one cup shaped chloroplast with a stigma, bigger ones can also be seen with up to three disc-shaped chloroplasts without stigma. Often autospores form a loose aggregate outside the empty sporangium, but they are neither united by the cell walls nor by secreted gelatinous substance, and therefore separate easily. During growth most cells (spores) soon lose their globular form, become ellipsoidic or asymmetric to fusiform (Fig. 7c) and soon multinucleated (Fig. $7 d$ ). Only once the development of much bigger daughter cells with thickened cell walls was observed. They were interpreted as resting cells.

Since the alga presented no exceptional features within the detailed light microscopic investigation with magnitudes up to $1,000-$ fold, that could influence the accurate diagnosis, there was no necessity to provide different views of the ultra-structural characters by electron micrographs. These data shall be presented in a different work.

Apart from the morphological findings, the genetic investigations show clearly that the new taxon is integrated in a special position within the system of the Xanthophyceae. Different mathematical and statistical analyses of the $r b c \mathrm{~L}$ gene in the first overview do not differ in the main results (Fig. 8, Fig. 9, see also for accession numbers): Excentrochloris fraunhoferiana is genetically different from a close group of Botrydiopsis species

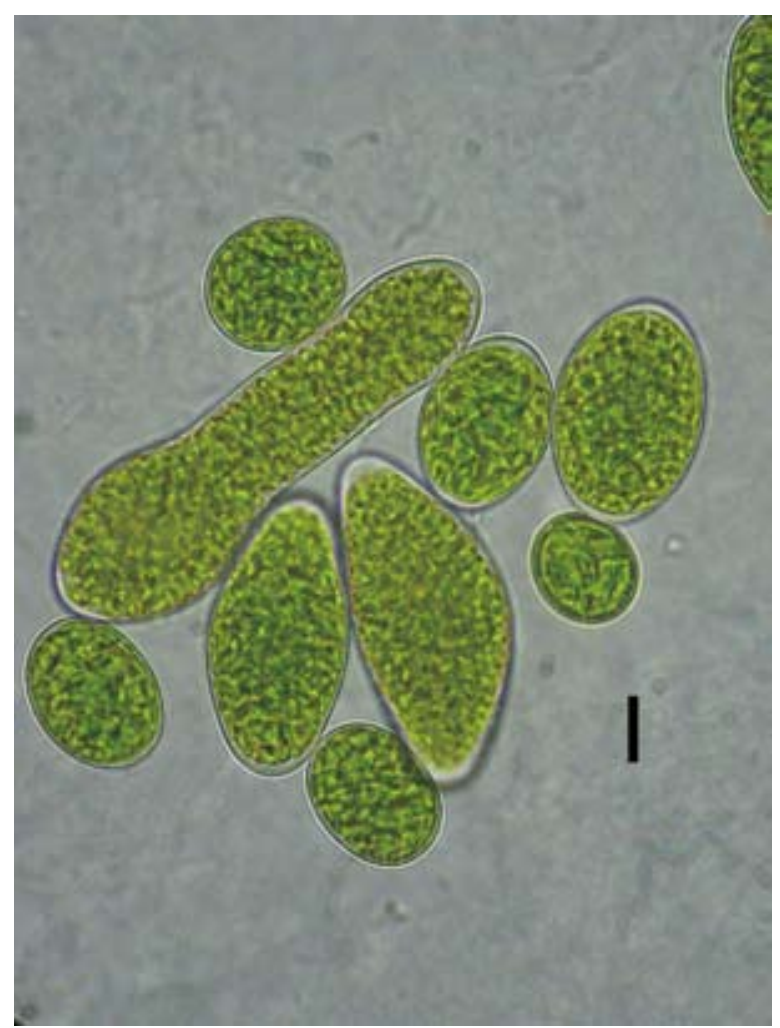

Fig. 2. Young coenoblasts with partly visible stacks of chloroplasts. Scale bar $10 \mu \mathrm{m}$.
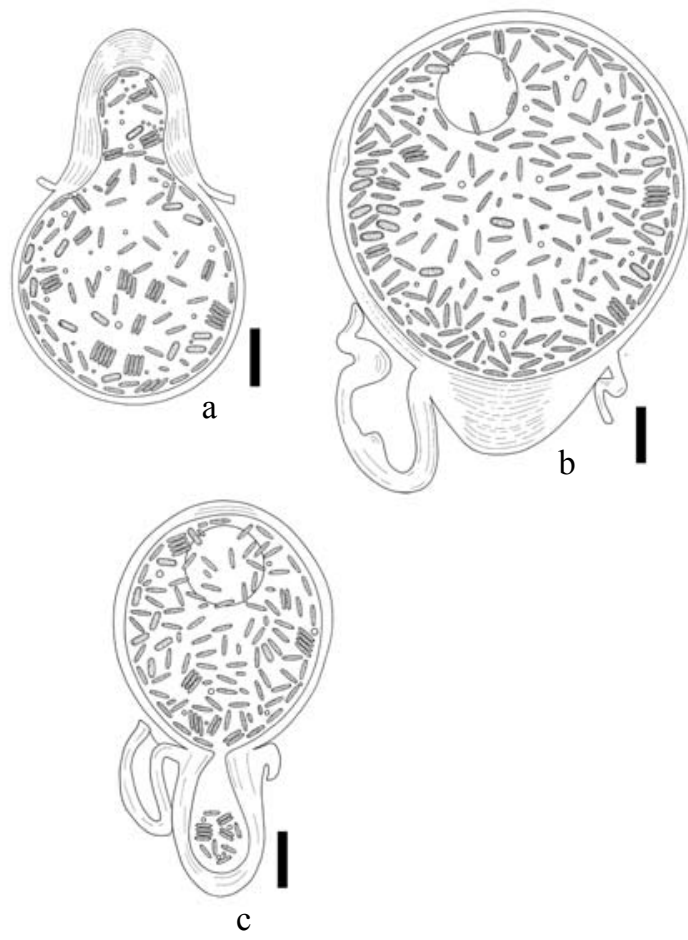

Fig. 3. Different mature coenoblasts which show a partial casting of the membrane. In (c) the different size of the chloroplasts in both parts of the cell indicates that there might be already two separated protoplasts, but in the light microscope no clear borderline could be seen. Scale bar $10 \mu \mathrm{m}$. 

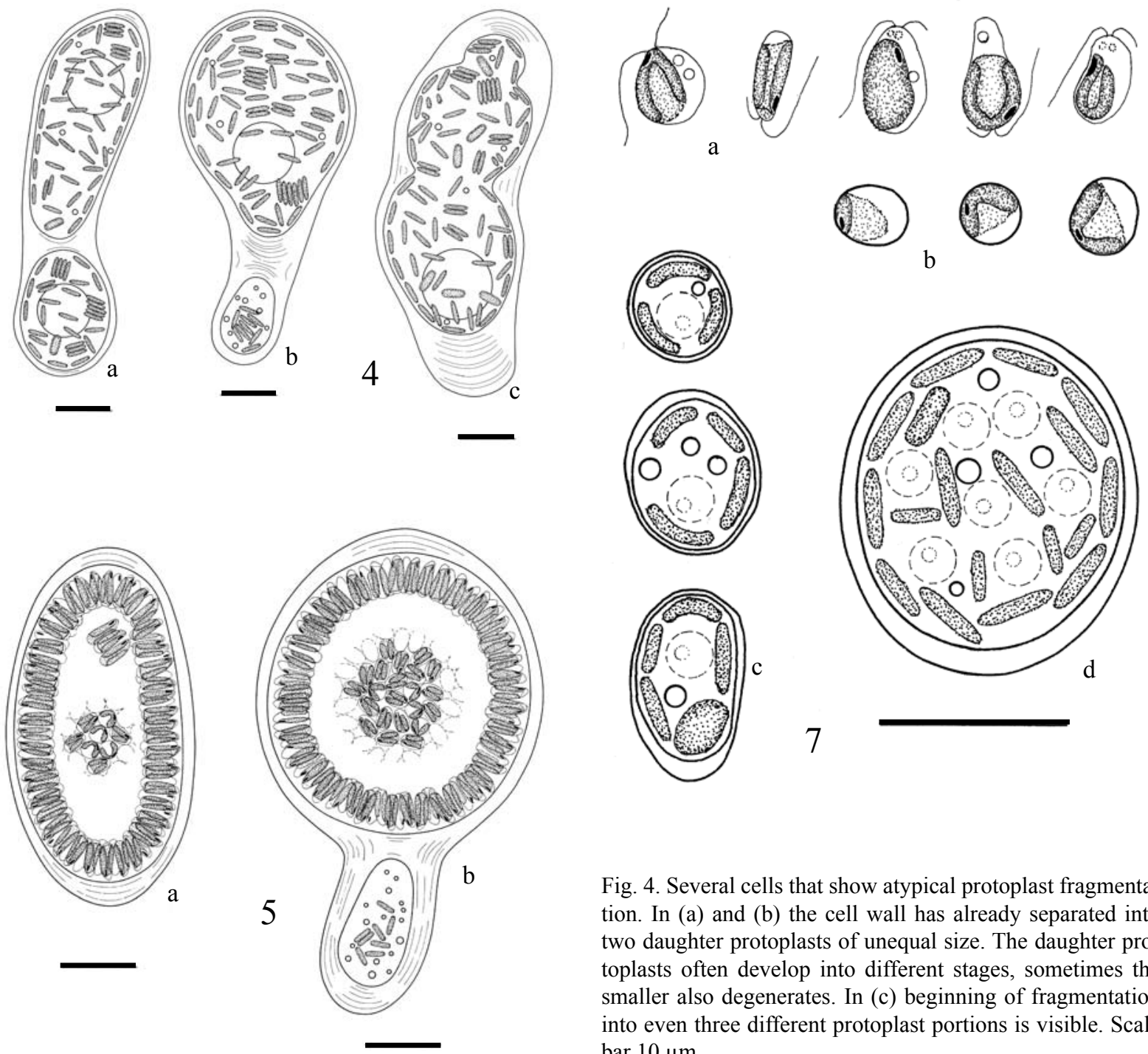

Fig. 4. Several cells that show atypical protoplast fragmentation. In (a) and (b) the cell wall has already separated into two daughter protoplasts of unequal size. The daughter protoplasts often develop into different stages, sometimes the smaller also degenerates. In (c) beginning of fragmentation into even three different protoplast portions is visible. Scale bar $10 \mu \mathrm{m}$.

Fig. 5. Zoosporangia shortly before liberation of the zoospores. The developed zoospores are already differentiated and arranged in the periphery of the cell, in the center plasma substance without chloroplasts. a) Sometimes a second partial group is visible In the centre of each sporangium a part of the regular arrangement of zoospores is drawn from top view. Each zoospore has only one chloroplast which bears a small red stigma apically. The flagella are scarcely visible with light microscope or not yet differentiated. For the second two-celled plant (b) the smaller protoplast is still in a vegetative phase. Scale bar $10 \mu \mathrm{m}$.

Fig. 6. Empty zoosporangia of a single cell (a) and a two celled aggregate (b). The zoosporangia open usually by a fissure, not at a formation in the wall. After the depletion of the zoospores a reticulate plasma residue is left. Soon after the burst of the sporangium the cell wall partially begins to swell (a). Scale bar $10 \mu \mathrm{m}$.

Fig. 7. (a) Zoospores and initial stages of cell development. (b) Juvenile cells developed from zoospores. They usually also show stigmata in an early stage of development. (c) In an early stage of the vegetative development the cells already contain several chloroplasts but still one nucleus. (d) Young vegetative and multinucleate cell. Scale bar $10 \mu \mathrm{m}$. 
Table 3. Comparison of different characteristics of E. fraunhoferiana sp. nov. and Botrydiopsis constricta BROADY (according to BROADY, 1976).

\begin{tabular}{|c|c|c|}
\hline Characteristic & Botrydiopsis constricta & Excentrochloris fraunhoferiana \\
\hline Size of adult cells & $25-42 \mu \mathrm{m}$ & various, up to $68-91-110 \mu \mathrm{m}$ \\
\hline Shape of adult cells & $\begin{array}{l}\text { spherical, sometimes ellipsoidal or ir- } \\
\text { regular }\end{array}$ & $\begin{array}{l}\text { pyriform to lageniform to fusiform or ir- } \\
\text { regular, rarely spherical }\end{array}$ \\
\hline Cell wall of adult cells & $\begin{array}{l}\text { Smooth and thin, occasionally with } \\
\text { thickenings }\end{array}$ & $\begin{array}{l}\text { Smooth and firm, often local lamellate } \\
\text { thickenings }\end{array}$ \\
\hline Stacks of plastids & unknown & Regularly observed in vegetative cells \\
\hline $\begin{array}{l}\text { Partial casting of the } \\
\text { membrane }\end{array}$ & unknown & $\begin{array}{l}\text { Sometimes observed in older vegetative } \\
\text { cells }\end{array}$ \\
\hline $\begin{array}{l}\text { Unusuall vegetative divi- } \\
\text { sion }\end{array}$ & $\begin{array}{l}\text { Division of whole coenoblasts by trans- } \\
\text { verse wall forming and constriction or } \\
\text { by a kind of budding, finally giving rise } \\
\text { to two liberated daughter cells }\end{array}$ & $\begin{array}{l}\text { Division of the protoplast in often differ- } \\
\text { ent sized daughter portions with further } \\
\text { different development by formation of } \\
\text { a transverse wall by unequal thickening } \\
\text { of the cell wall. Never liberation of the } \\
\text { daughter cells, daughter protoplast al- } \\
\text { ways remaining connected by the mother } \\
\text { cell wall. Sometimes even indication of } \\
\text { a further division. }\end{array}$ \\
\hline Attributes of zoospores & $\begin{array}{l}\text { Naked, unequally biflagellate, one chlo- } \\
\text { roplast with stigma; metabolic to amoe- } \\
\text { boid (pseudopodia) }\end{array}$ & $\begin{array}{l}\text { Naked, unequally biflagellate, one chlo- } \\
\text { roplast with stigma; metabolic but no } \\
\text { formation of pseudopodia }\end{array}$ \\
\hline $\begin{array}{l}\text { Plasma residue after spore } \\
\text { release }\end{array}$ & unknown & Reticulate residue always present \\
\hline
\end{tabular}

around the type species $B$. arhiza Borzi. The investigated strains of the new species are grouped in a clade directly beside $B$. constricta BROADY but the separation between these two forms is well supported, both after Bayesian Analysis (fifure 8) and Parimony analysis (figure 9). Both forms are within a major phyletic line with Mischococcus NAEgELI and Heterococcus CHODAT according to Bayesian Analysis. B. pyrenoidosa H. TRenKwalder is always grouped at the base of the Xanthophyceae and can even be used as outgroup. Because the phylogenetic analysis of SSU-sequences provides similar results these are not shown here.

\section{Discussion}

The algal class Xanthophyceae, in sense of FriTsCH (1935), HibBerd \& LeEdAle $(1971 \mathrm{a}+\mathrm{b})$ and HibBERD (1981) forms a well defined group within the Heterokontophyta. According to ADL (2005) the class Xanthophyceae is divided into two oders: Tribonematales PASCHER und Vaucheriales Bohlin. Recent more detailed insight in the phylogeny of the algal class Xanthophyceae is given by MaIstro et al. (2009). Taxa with a coenocytic main life form are distributed within the Xanthophyceae in different families respectively orders (EtTl 1978; Rieth 1980; ANDERSEN \& BAILEY 2002). Different works with a genetic emphasis indicate that there are different lines of evolution 


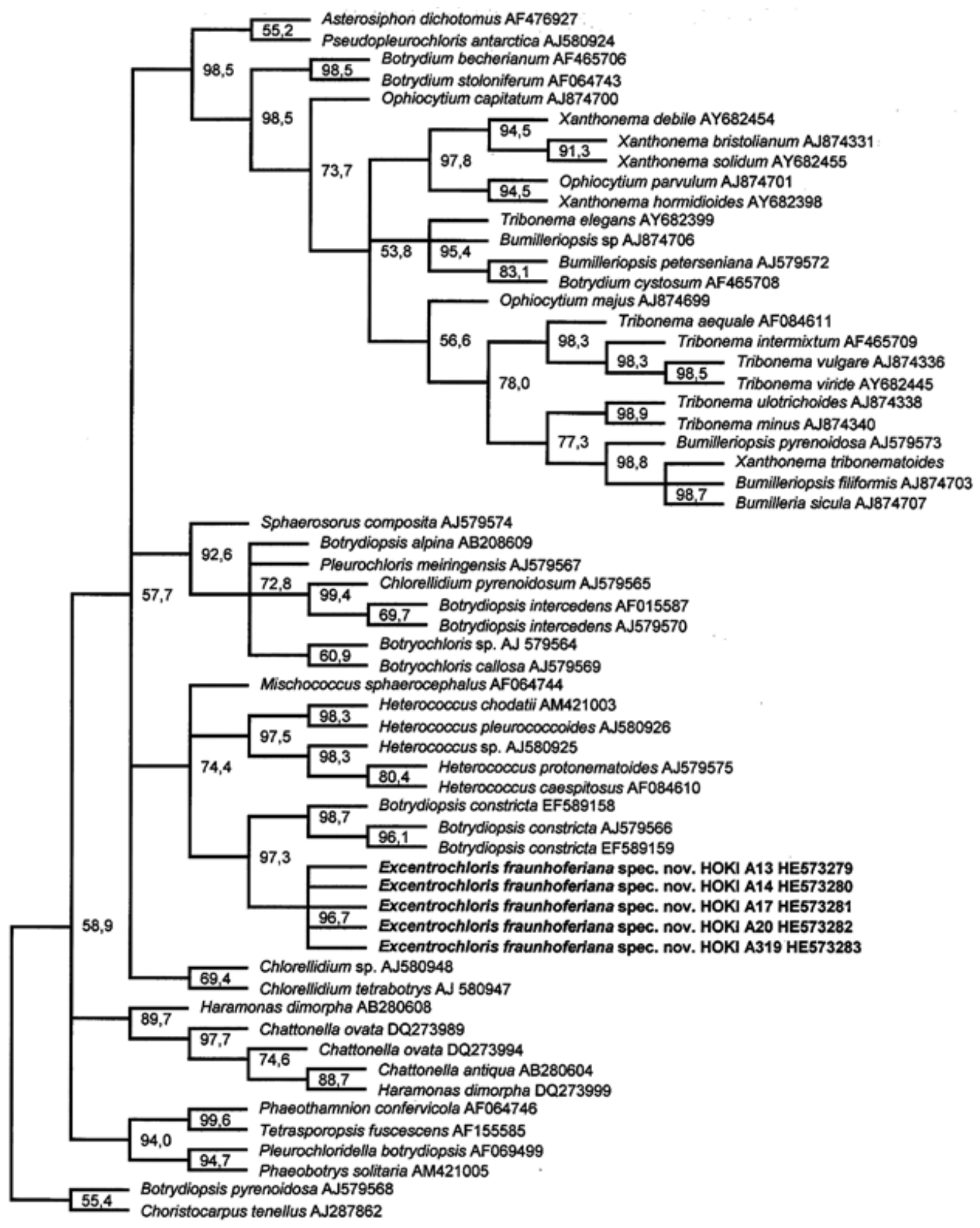

Fig. 8. $r b c \mathrm{~L}$-sequence phylogenetics of the Xanthophyceae, with Excentrochloris fraunhoferiana sp. nov. included. Tree topology reconstructed using Bayesian Analysis. Support values at nodes are given as bootstrap percentage.

within the Xanthophyceae, each with convergent developmental stages comparable to the chlorophyceae (PotTer et al. 1997; MAistro et al. 2009). According to these genetic data a complete rearrangement would be needed, but the data base is still insufficient or inconsistent (ANDERSEN \& BAILEY 2002; MAistro et al. 2009).

For the genus Excentrochloris PASCHER, with the type species E. gigas PASCHER, description and figures in PASCHER (1939) are valid as 


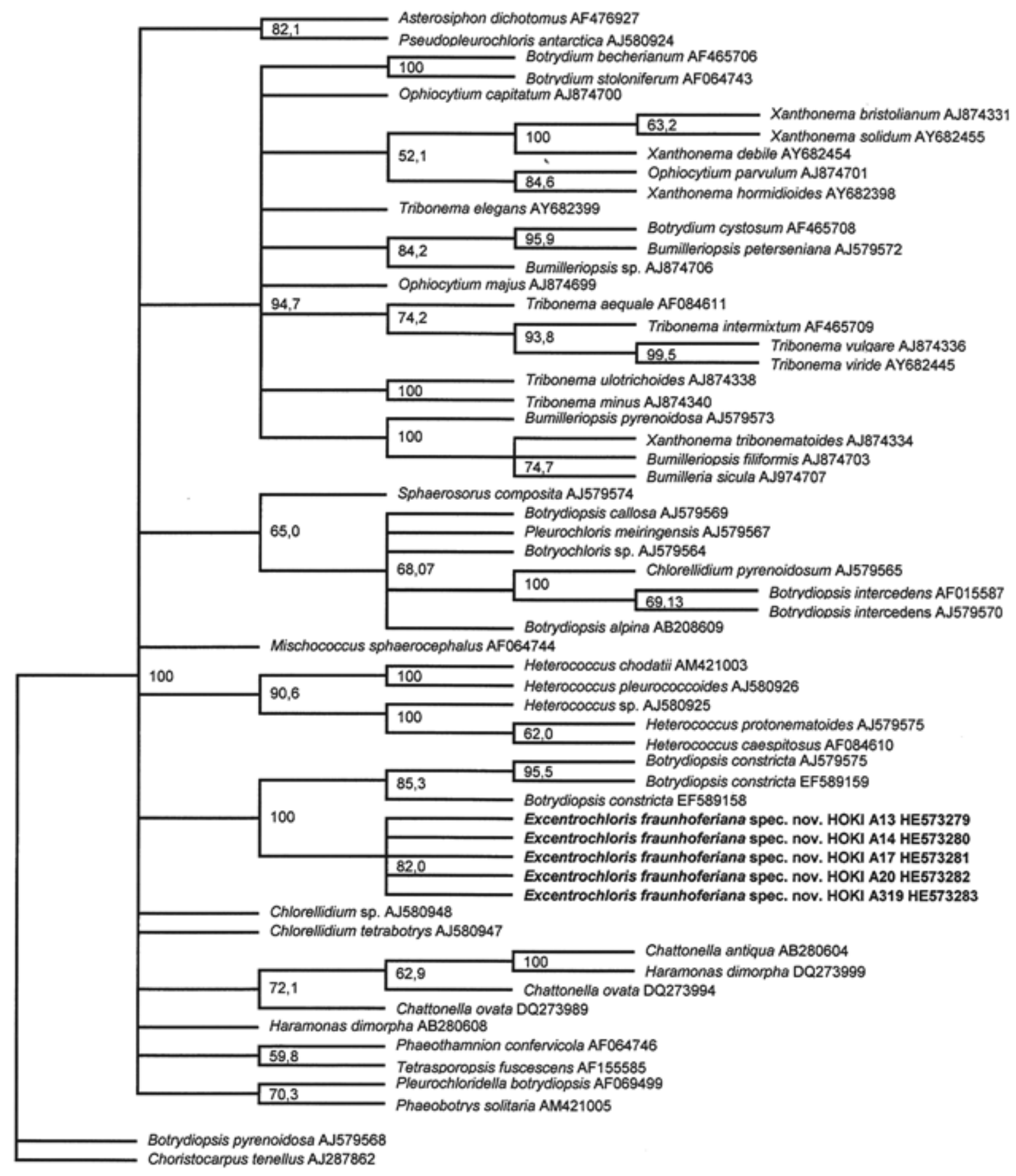

Fig. 9. $r b c \mathrm{~L}-$ sequence phylogenetics of the Xanthophyceae, with Excentrochloris fraunhoferiana sp. nov. included. Tree topology reconstructed using Parsimony Analysis. Support values at nodes are given as bootstrap percentage.

lecto- and iconotypus; cultures of the typus do not exist. The coenocytic genus is characterized above all by an irregular shape of the cells, often from a young stage on and by partially, often one-sided, layered membrane thickenings. Adult cells possess numerous chloroplasts and the propagation is facilitated by metabolic zoospores or autospores. Resting cells may also occur. Furthermore, PASCHER (1939) declares that in old cells bleached chloroplasts may form a net like connection. This is interpreted in ETTL (1968) as an indication of cell degeneration.

Obviously, it must be a rare taxon. PAScher (1939) mentions similar forms from algae coats on reed stalks and from Nile mud without addressing them closer. ЕттL (1968) documented under the name E. gigas a smaller but also aquatic form. The first isolate of an Excentrochloris- like alga 
from soil was done by VinatZer as $E$. sp. and cultivated in ASIB (VINATZER 1975; GÄRTNER 1976, 1985). A subculture of this strain in the Culture Collection of Algae at Göttingen/Germany (SAG) is kept there as Botrydiopsis intercedens PASCHER. This strain occasionally forms ellipsoidal to lenticular coenoblasts, but apart from that it has more in common with the genus Botrydiopsis than with Excentrochloris.

Morphologically relations of $E$. fraunhoferianum with $B$. constricta can be established (shape of cells and membrane thickenings). In table 3 the different characters of $E$. fraunhoferiana and $B$. constricta are summarized. The newly found $E$. fraunhoferiana shows, in contrast with $B$. constricta, nearly always irregular shape and local layered membrane thickenings, whereby the affiliation to Excentrochloris becomes evident. $B$. constricta was obviously included in the genus Botrydiopsis by BROADY (1976), because it shows mainly spherical coenoblasts and other cell shapes are rare. But in other species of the genus Botrydiopsis occasional divergence from the spherical cell shape is known (ETTL 1978; ETTL \& GÄRTNER 1995). B. constricta was only documented from the Antarctic (BROADY 1976), but recently was again recorded from mountainous regions of New Zealand (Novis et al. 2008).

Recent genetic investigations indicate that the genus Botrydiopsis is polyphyletic and therefore should be divided (Negrisolo et al. 2004; MAistro et al. 2009). For B. pyrenoidosa it is even uncertain if it should be placed at the basis of the Xanthophyceae or if it belongs to a different group of algae because it is genetically so different (Fig. 8, 9). In this investigation it therefore could be used as an outgroup. In current investigations already a new name is proposed: Polykaryon pyrenoidosum (Misner 2004; J.C. Bailey, personal comment, in press). For $B$. constricta it was shown that it certainly belongs to the Xanthophyceae but it groups at a distinct position far from the other species of the genus Botrydiopsis (NEGRISOlo et al. 2004; MAISTRO et al. 2009). According to our investigations $B$. constricta together with the new isolates from New Zealand (in concordance with Novis et al. 2008) and E. fraunhoferiana lay close together. If this means that they are two species of a single genus or if they resemble species from two different but closely related genera remains to be shown in future investigations. Because of the fact that the presented phylogenetic data are of an overview character further detailed investigations shall be done.

Within the artificial family Botrydiopsidaceae some more genera exist, but many of them need further revision and investigation (BOURRELLY 1968; ETTL, 1978). Recently it has been shown (JUÁREZ et al. 1998), that young plants from a Botrydium sp. also may develop stages that are strongly suggestive of Botrydiopsis (coccale stage with spherical cells) and Excentrochloris (irregular cellform and local membrane thickenings). In cultures these stages immediately begin to grow into typical thalli.

As a further step it is planned to assess the ecophysiological capacity of Excentrochloris fraunhoferiana (e.g. temperature range, light requirement, tolerance of different humidity's and/ or solute concentrations). Since the alga produces oil substance it might also be an interesting strain for biotechnology. It has already been shown that Xanthophyceae might be grown under chemoorganic conditions (CASSELTON 1966).

\section{Acknowledgements}

The work for this paper was done with the support of the Fraunhofer-Institute for Building Physics (Holzkirchen, Germany). For graphical aid the authors want to thank Werner Conrad (Holzkirchen, Germany) and Georg Höck (Kufstein, Austria). For the English correction of the manuscript great thank is due to Prof. James Dickson (Glasgow University, Scotland). Many thanks also for scientific input to J. Craig Bailey (University of North Carolina at Wilmington, USA).

\section{References}

Adl, S.M., Simpson, A.G.B., Farmer, M.A., Andersen, R.A., Anderson, O.R., Barta, J.R., Bowser, S.S., Brugerolle, G., Fensome, R.A., FrederICQ, S., James, T.Y., Karpov, S., Kugrens, P., Krug, J., Lane, C.E., Lewis, L.A., Lodge, J., Lynn, D.H., Mann, D.G., Mccourt, R.M., Mendoza, L., Moestrup, Ø., Mozley-Standridge, S.E., Nerad, T.A., Shearer, C.A., Smirnov, A.V., Spiegel, F.W. \& TAYlor, M.F.J. (2005): The new higher level classification of Eukaryotes with emphasis on the taxonomy of protists. - J. Eukaryot. Microbiol. 52: 399-451.

Andersen, R.A. \& BAiley, J.C. (2002): Phylogenetic analysis of 32 strains of Vaucheria (Xanthophyceae) using the $r b c \mathrm{~L}$ gene and its two flanking spacer regions. - J. Phycol. 38: 583-592. 
Aslam, Z., Shin, W., Kim, M.K., Im, W.-T., Lee, S.-T. (2007): Marinichlorella kaistiae gen. et sp. nov. (Trebouxiophyceae, Chlorophyta) based on polyphasic taxonomy. - J. Phycol. 43: 576-584.

Bischoff, W.W. \& Bold, H.C. (1963): Phycological Studies. IV. Some soil algae from Enchanted Rock and related species. Univ. Texas Publ. 6318: 1-95.

Borzi, A. (1889): Botrydiopsis, nuovo genere di alghe verde. - Boll. Soc. Ital. Microscop. 1: 66-70.

Borzi, A. (1895): Studi algologici. - Saggio di ricerche sulla biologia delle alghe. Fasc. 2: 118-378.

Bourrelly, P. (1968): Les algues d'eau douce. - 438 pp., Tome II. Boubeé, Paris.

Broady, P.A. (1976): Six new species of terrestrial algae from Signy Island, South Orkney Islands, Antarctica. - Br. phycol. J. 11: 387-405.

Casselton, P.J. (1966): Chemo-organotrophic growth of xanthophycean algae. - New Phytol. 65: 134-140.

DAles, R.P. (1960): On the pigments of the Chrysophyceae. - J. mar. boil. Ass. U.K. 39: 693-699.

Daugberg, N. \& Andersen, R.A. (1997): Phylogenetic Analyses of the $r b c \mathrm{~L}$ Sequences from Haptophytes and Heterokont Algae Suggest Their Chloroplasts are Unrelated. - Mol. Biol. Evol. 14: 1242-1251.

DüRINGER, I. (1958): Über die Verteilung epiphytischer Algen auf den Blättern wasserbewohnender Angiospermen sowie systematisch-entwicklungsgeschichtliche Bemerkungenüber einige grüne Algen. - Österr. Bot. Z. 105: 1-43.

Etтl, H. (1968): Ein Beitrag zur Kenntnis der Algenflora Tirols. - Ber. Nat.-med. Ver. Innsbruck Band 56: 177-354.

Eтtr, H. (1978): Xanthophyceae 1. Teil. - In: EтtL, H., Gerloff, J. \& Heynig, H. (eds): Süsswasserflora von Mitteleuropa 3. - 530 pp., Gustav Fischer, Stuttgart, New York.

EtTL, H. \& GäRTner, G. (1988): Chlorophyta II. Tetrasporales, Chlorococcales, Gloeodendrales. - In: Ettl, H., Gerloff, J., Heynig, H. \& Mollenhauer, D. (eds): Süsswasserflora von Mitteleuropa 10. - 436 pp., Gustav Fischer, Stuttgart, New York.

Ettr, H. \& Gärtner, G. (1995): Syllabus der Boden-, Luft- und Flechtenalgen. - 721 pp., Gustav Fischer, Stuttgart, Jena, New York.

FRITSCH, F.E. (1935): The structure and reproduction of the algae. I. - 939 pp., University Press, Cambridge.

GärTnER, G. (1976): Verzeichnis der Algenkulturen am Institut für Botanische Systematik und Geobotanik der Universität Innsbruck. - Ber. Nat.med. Ver. Innsbruck 63: 67-89.

GärTNER, G. (1985): The culture collection of algae at the Botanical Institute of the University at Innsbruck (Austria). - Ber. nat.--med. Ver. Innsbruck
72: $33-52$.

GÄrtner, G. (2004): ASIB - The Culture Collection of Algae at the Botanical Institute, Innsbruck, Austria. - Nova Hedwigia 79: 71-76.

HibBerd, D.J. (1981): Notes on the taxonomy and nomenclature of the algal classes Eustigmatophyceae and Tribophyceae (synonym Xanthophyceae). - Bot. J. Linn. Soc. 82: 93-119.

Hibberd, D.J. \& Leedale, G.F. (1971a): A new algal class - The Eustigmatophyceae. - Taxon 20: 523-525.

Hibberd, D.J. \& Leedale, G.F. (1971b): Cytology and Ultrastructure of the Xanthophyceae II. The zoospore and vegetative cell of coccoid forms, with special reference to Ophiocytium majus NAEgeli. - Br. Phycol. J. 6: 1-23.

Hofbauer, W. (2007): Aerophytische Organismen an Bauteiloberflächen. Dissertation. - 436 pp., Leopold-Franzens Universität Innsbruck.

Huelsenbeck, J.P, \& RonQuist, F. (2001): MRBAYES: Bayesian inference of phylogenetic trees. - Bioinformatics 17: 754-755.

Juárez, A.B., Alberghina, J.S., Vélez, C.G. (1998): Culture studies of Botrydiopsis-like morphotypes isolated from a neustonic population of Botrydium (Tribophyceae, Chromophyta). - Algological Studies 91: 109-115.

KoL, E. (1970): Algae from the soil of the Antarctic. Acta Bot. Acad. Sci. Hungar. 16: 313-319.

Maistro, S., Broady, P.A., Andreoli, C. \& Negrisolo, E. (2009): Phylogeny and Taxonomy of Xanthophyceae (Stramenopiles, Chromalveolata). - Protist 160: 412-426.

Misner, I. (2004): Morphological \& phylogenetic analysis of two species of heterokont alage. Thesis. - 64 pp., University of North Carolina at Wilmington.

Negrisolo, E., Maistro, S., Incarbone, M., Moro, I., Dalla Valle, L., Broady, P.A. \& Andreoli, C. (2004): Morphological convergence characterizes the evolution of Xanthophyceae (Heterokontophyta): evidence from nuclear SSU rDNA and plastidal $r b c \mathrm{~L}$ genes. - Mol. Phylogenet. Evol. 33: 156-170.

Neustupa, J., NĚmcová, Y., Eliáš, M., ŠKaloud, P. (2009): Kaliniella bambusicola gen. et sp. nov. (Trebouxiophyceae, Chlorophyta), a novel coccoid Chlorella-like subaerial alga from Southeast Asia. - Phycol. Res. 57: 159-169.

Novis, P.M., Beer, T., Vallance, J. (2008): New records of microalgae from the New Zealand alpine zone, and their distribution and dispersal. - New Zeal. J. Bot. 46: 347-366.

PAscher, A. (1939): Heterokonten. - In Rabenhorst's Kryptogamenflora von Deutschland, Österreich und der Schweiz. Vol.11. - 1092 pp., Leipzig.

PetrovÁ, J. (1931): Die vermeintliche Heterokonte „Botrydiopsis“ minor - eine Chlorophycee. - 
Beih. Bot. Centralbl. 48: 221-228.

Potter, D., SAunders, G.W. \& Andersen, R.A. (1997): Phylogenetic relationships of the Raphidophyceae and Xanthophyceae as inferred from nucleotide sequences of the $18 \mathrm{~S}$ ribosomal RNA gene. - A. J. Bot. 84: 966-972.

Pröschold, T. \& Leliaert, F.(2007): Systematics of the green algae:conflict of classic and modern aproaches. - In: Brodie, J. \& Lewis, J. (eds): Unravelling the Algae: The Past, Present and Future of Algal Systematics. The Systematics Association Special Volume Series 75. - pp. 123-153, CRC Press, Boca Raton, London and New York.

Rieth, A. (1980): Xanthophyceae 2. Teil. - In: Ettl, H., Gerloff, J. \& Heynig, H. (eds): Süsswasserflora von Mitteleuropa 4. - 145 pp., Gustav Fischer, Stuttgart, New York.

SiLVA, P.C. (1980): Remarks on algal nomenclature VI. - Taxon 29: 121-145.

SNOw, J.W. (1902): The plankton algae of Lake Erie, with special reference to the Chlorophyceae. U.S. Fish. Com. Bull. 1902: 369-394.

Sundberg, K., O’Connor, T., Carroll, H., Clement, M. \& SNell, Q. (2008): Parsimony accelerated Maximum Likelihood searches. - Int. J. Computational Biology and Drug Design 1: 74-87.
Swofford, D.L. (2003): PAUP*. Phylogenetic Analysis Using Parsimony (*and Other Methods). Version 4b10. - Sinauer Associates, Sunderland MA. (Program).

Trenkwalder, H. (1975): Neue Bodenalgen aus Föhrenwäldern im Raum von Brixen (Südtirol, Italien). - Ber. nat.-med. Ver. Innsbruck 62: 7-19.

TschermaK-Woess, E. (1979): Über Plastidenstapel bei Botrydiopsis alpina sowie Anlage und Vermehrung der Stigmen bei dieser und Heterococcus (Xanthophyceae). - Pl. Syst. Evol. 131: 179192.

Viala, G. (1966): Botrydiopsis pyrenaica nov. esp. - Société Botanique de France, Séances 113: 291-295.

VinAtZer, G. (1975): Untersuchungen über die Bodenalgen in der alpinen Stufe des Pitschberges (2.300 m), Südtirol. - 142 pp., Dissertation Universität Innsbruck.

VISCHER, W. (1945): Heterokonten aus alpinen Böden, speziell dem Schweizer Nationalpark. Ergebnisse wiss. - Unters. Schweizer Nationalparks 1: 481-512.

Wilhelm, C., Krämer, P. \& Wiedemann, I. (1987): Die Lichtsammelkomplexe der verschiedenen Algenstämme. - Biologie in unserer Zeit 17: 138-143.

(C) Czech Phycological Society (2011)

Received May 15, 2010

Accepted December 9, 2010 